\title{
Ovarian Sertoli-Leydig Cell Tumor, Multinodular Goiter, Cystic Nephromas and DICERI Mutations: Case Report and Literature Review
}

\author{
Yanglin $\mathrm{Ni}^{1}$ \\ Xuan Zhou ${ }^{2}$ \\ Ling $\mathrm{Wu}^{3}$ \\ Ping $\mathrm{Wu}^{3}$ \\ Ying Liu ${ }^{3}$ \\ Yinnan $\mathrm{Li}^{3}$ \\ $\mathrm{Li} \mathrm{Cai}{ }^{3}$ \\ Xueshu $\mathrm{Fu}^{3}$ \\ Chunhua Zhang ${ }^{3}$ \\ 'Department of Gynaecology, Huai'an \\ Hospital of Traditional Chinese Medicine, \\ Huai'an, Jiangsu Province, People's \\ Republic of China; ${ }^{2}$ MyGenostics Inc., \\ Beijing, People's Republic of China; \\ ${ }^{3}$ Department of Gynaecology, Huai'an \\ Maternal and Child Health Hospital, \\ Huai'an, Jiangsu Province, People's \\ Republic of China
}

\begin{abstract}
Introduction: DICERI syndrome is a rare tumor predisposition syndrome caused by germline DICER1 mutation, which is related to a variety of benign and malignant diseases. Our report is the first described case of these three disease phenotypes of DICER1 syndrome. The female patient with a novel germline DICER1 nonsense mutation (c.1088_1089delCTinsAA p. $\mathrm{F} 363 \mathrm{X}$ ) in exon 8 that was inherited from her mother. In addition to germline DICERI mutation, two different hotspot somatic DICER1 mutations were detected in her ovarian tissue and goiter tissue. Our report will expand the report of DICER1 mutations in DICER1syndrome-related diseases and provide case references for further research in the future.

Conclusion: When the related disease phenotype appears in childhood, it should be considered whether it is DICERI syndrome. Genetic testing can help diagnose DICERI syndrome and develop related surveillance strategies. Awareness of the DICER1 syndrome may result in early recognition of these rare pediatric tumors and appropriate therapeutic management.
\end{abstract}

Keywords: case report, DICER1, Sertoli-Leydig cell tumor, multinodular goiter, cystic nephroma

\section{Introduction}

DICER1 syndrome is also known as pleuropulmonary blastoma family tumor susceptibility syndrome, shows a large spectrum of clinical phenotypes. Affected individuals are at increased risk of developing pleuropulmonary blastoma, cystic nephroma $(\mathrm{CN})$, rhabdomyosarcoma, multinodular goiter $(\mathrm{MNG})$, thyroid cancer, ovarian Sertoli-Leydig cell tumors (SLCTs), Wilms tumor, renal sarcoma, pineoblastoma, pituitary blastoma, and other neoplasia. ${ }^{1-4}$ SLCTs are a rare type of sexcord stromal tumors in the ovary. ${ }^{5}$ SLCTs have been classified into three histologic types by World Health Organization, that is well differentiated, moderately differentiated, and poorly differentiated, and almost all of the moderately and poorly differentiated tumors harbor DICER 1 mutation. ${ }^{6} \mathrm{MNG}$ is a common disease characterized by nodular hyperplasia of the thyroid. MNG is also a frequent manifestation of DICER 1 syndrome. ${ }^{7,8}$ Individuals with DICER1 mutations have 16-24 times the risk of developing thyroid cancer than the general population. Thyroid cancers associated with DICER 1 syndrome are usually follicular or papillary. ${ }^{9} \mathrm{CN}$ is also called multilocular cystic nephroma, which is an uncommon benign renal neoplasm. ${ }^{10,11} \mathrm{CN}$ associated with DICER1 syndrome usually occurs in children
Correspondence: Chunhua Zhang Department of Gynaecology, Huaian Maternal and Child Health Hospital, Huai'an, Jiangsu Province, People's

Republic of China

Tel +86I3952326II 7

Email hafyzch@yeah.net 
below 2 years of age. ${ }^{12}$ Here we present a patient with a history of CN who was diagnosed with SLCT and MNG.

\section{Patient Information}

At 17 years of age, the patient came to the hospital due to a pelvic mass found on physical examination. Anal examination found that the right appendage touched a mass with medium texture and good mobility. Color Doppler ultrasound showed that the right ovary was unclear, and the pelvic cavity had mixed cystic and solid masses. MRI examination revealed a huge cystic solid mass in the pelvic cavity, measuring $10.48 \times 8.31 \times 12.92 \mathrm{~cm}$. She immediately underwent unilateral oophorectomy and subsequent histopathological examination detected showed ovarian sex cord stromal tumor, considering medium-low differentiated Sertoli-Leydig cell tumor (Figure 1).

Later, the patient was admitted to the hospital again with a history of thyroid sarcoidosis. The right lobe of the thyroid could palpate a mass of about $2 * 1.5 \mathrm{~cm}$ in size. The left lobe of the thyroid had no obvious mass. The lymph nodes in both necks were not significantly enlarged. Color Doppler ultrasound results showed that there were multiple isoechoic nodules in the two leaves. The largest nodule on the right was $2.22 * 1.57 \mathrm{~cm}$, and the largest size of the left nodule was $1.54 * 1.00 \mathrm{~cm}$. The results of the puncture pathological diagnosis suggested that the right lobe of the thyroid gland was suspected to be papillary thyroid carcinoma. Therefore, the patient was operated under anesthesia. Postoperative pathology showed: papillary carcinoma of the right thyroid lobe, bilobular multinodular goiter (Figure 2).

The patient had a previous medical history. A mass in the left upper abdomen was found when the patient was almost 2 years old. After neoadjuvant chemotherapy, she underwent left nephrectomy. Postoperative pathology revealed multilocular cystic nephroma in the left kidney.

Since the patient had multiple diseases, the clinician suspected a DICER1 mutation. By using high-throughput

\section{A}

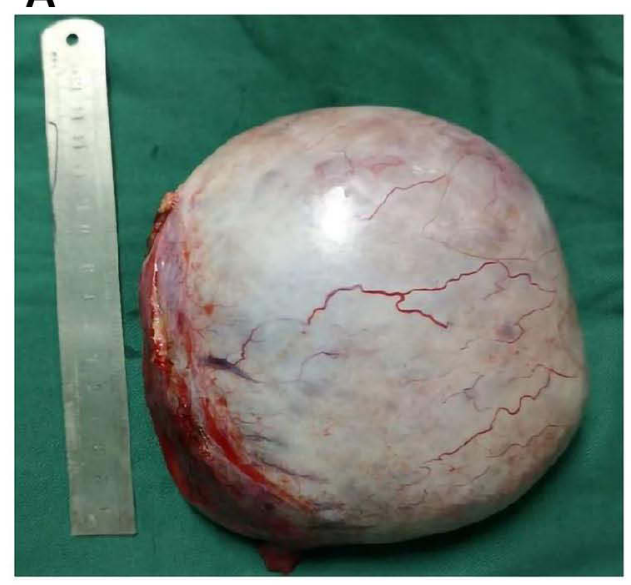

C

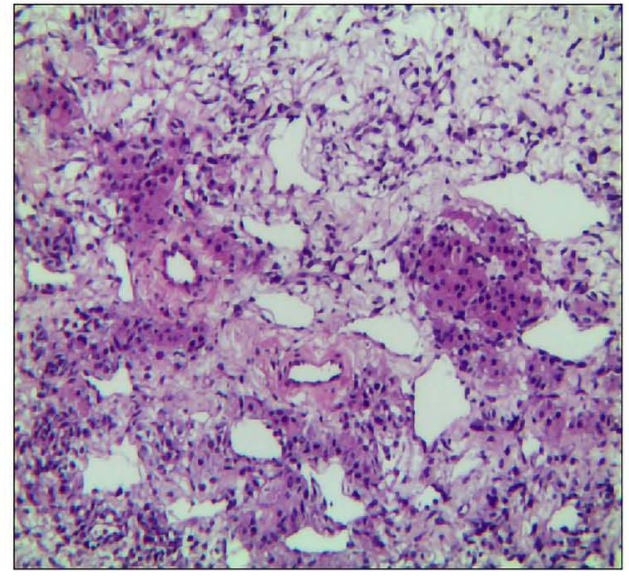

B

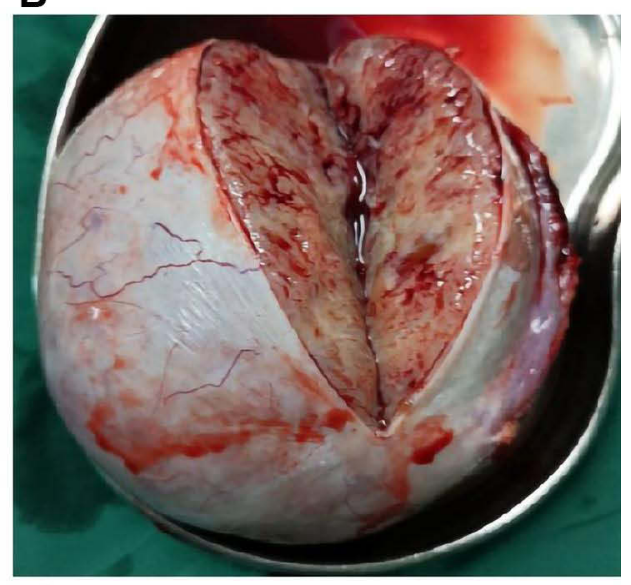

D

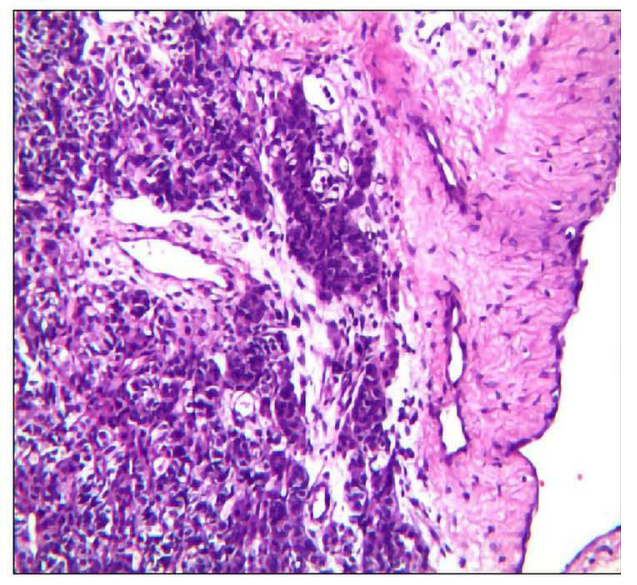

Figure I (A and B) Ovary and ovarian profile; (C and D) ovarian Sertoli-Leydig cell tumor of medium-low differentiation (HES $\times 400)$. 
A

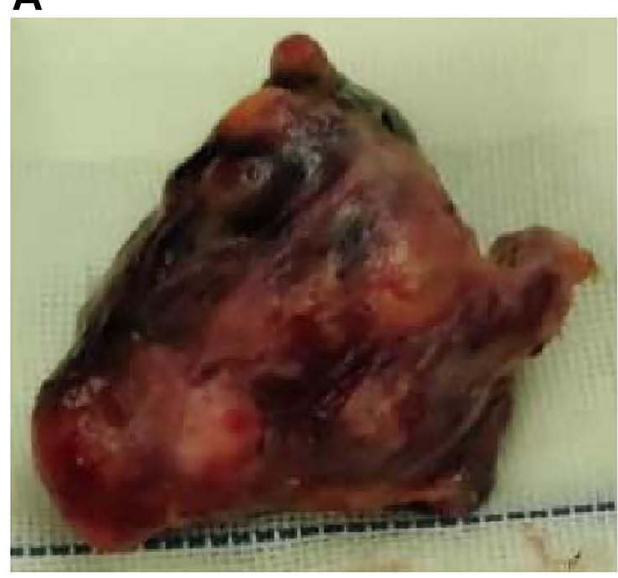

C

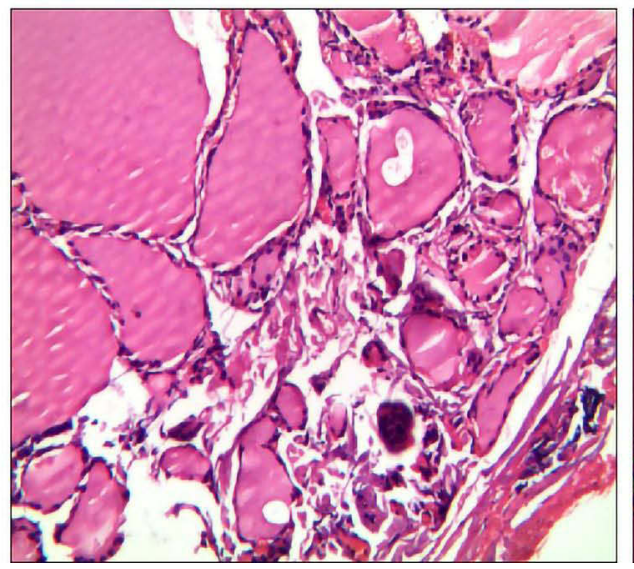

B

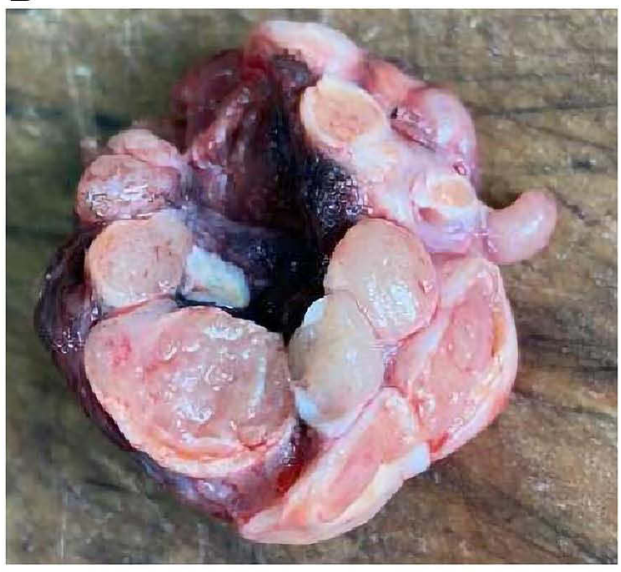

D

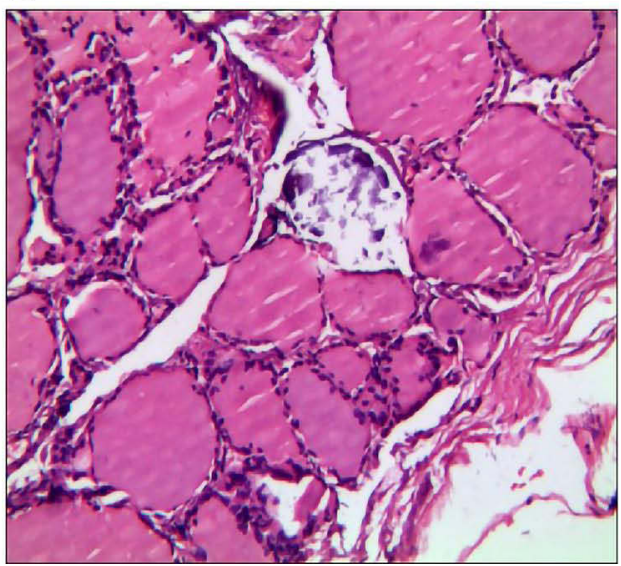

Figure 2 (A and B) Thyroid and thyroid profile; $(\mathbf{C}$ and $\mathbf{D})$ multinodular goiter $(\mathrm{HES} \times 400)$.

target sequencing (MyGenostics, Beijing, China) of a panel of genes involved in tumor development, including entire coding region and the exon-intron boundaries of DICER 1, we identified a heterozygous nonsense germline DICER1 mutation (c.1088_1089delCTinsAA p.F363X). The mutation was confirmed by Sanger sequencing (Figure 3A). Sequencing revealed that her DICER1 mutation was inherited from her mother (Figure 3B).

To further identify the genetic mutation profile, we performed whole-exome gene sequencing (MyGenostics, Beijing, China), using ovarian tumor tissue and thyroid tumor tissue as samples, and blood as the control. Molecular studies have revealed that these two lesions harbored distinct genetic mutations. Ovarian tissue revealed somatic mutation in DICER1 missense mutation in the exon 25 (c.5428G $>$ T p. D1810Y) with the variant allele frequency of $50 \%$ (Figure $3 \mathrm{C}$ ), and thyroid tissue revealed somatic mutations in DICER1 missense mutation in exon 24 (c.5126A $>$ G p.D1709G) with the variant allele frequency of $24 \%$ (Figure 3D). The two different somatic DICER1 mutations were all located in the RNase IIIb domain of DICER1 gene. Both of somatic mutations had been reported in previous studies. ${ }^{1,13,14}$

\section{Discussion}

Germline mutations in DICER1 are associated with DICER 1 -related disorders. Recent research shows that Mesenchymal hamartoma of the liver (MHL) is also a new phenotype of DICER1 syndrome. ${ }^{15}$ However, our report is the first described case of a patient with a history of CN who was diagnosed with SLCT and MNG. Our case report adds evidence for the description of the phenotypes of DICER1 syndrome. When there are later cases who were diagnosed with cystic nephroma at an early age, relevant genetic testing should be done as soon as possible to prevent other related diseases early.

Moreover, many cases report that ovarian SLCT and MNG can be associated with DICER1 mutations (Table 1). The novel 
A
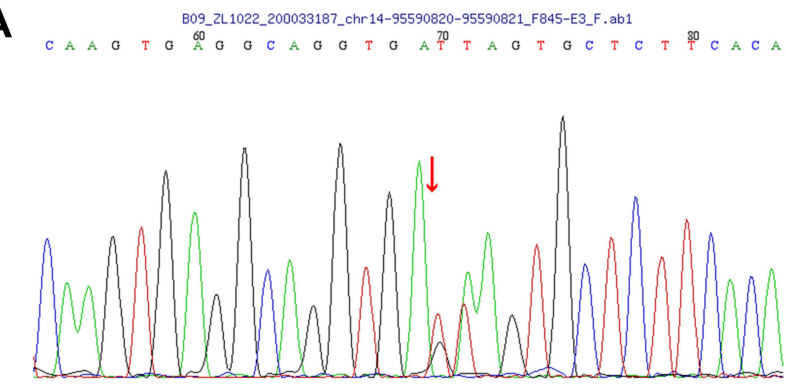

C File Genomes View Tracks Regions tools Genomespoce Help

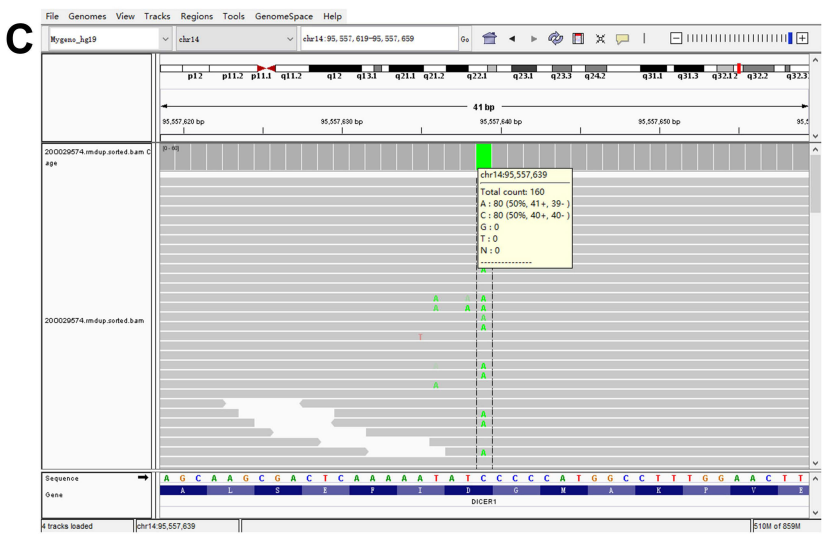

B

C06_ZL1022_200033189_chr14-95590820-95590821_F650-H4_F.ab1

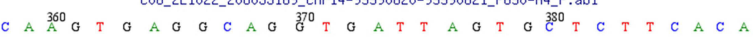

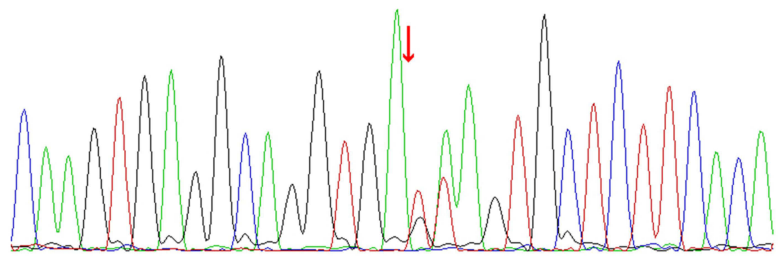

D
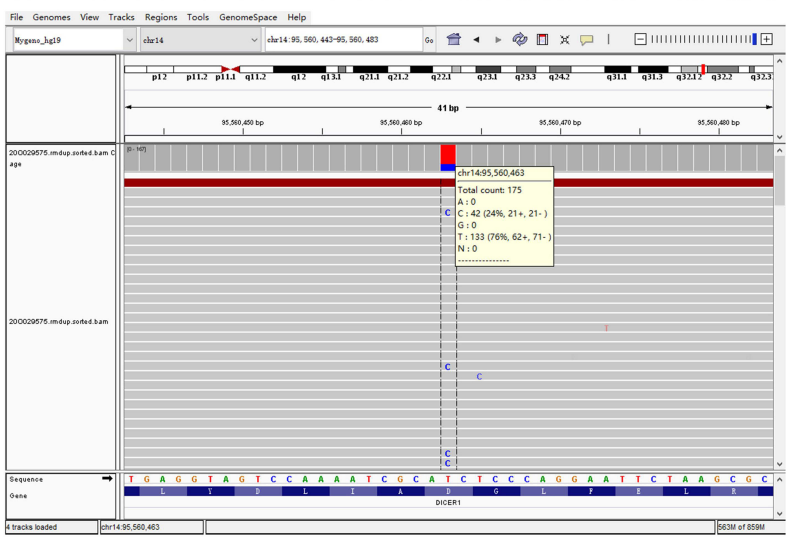

Figure 3 (A) Germline DICERI mutation (c.I088_1089delCTinsAA p.F363X) of the patient was confirmed by Sanger sequencing. (B) Germline DICERI mutation (c.1088_1089delCTinsAA p.F363X) of the patient's mother was confirmed by Sanger sequencing. (C) Somatic DICERI missense mutation in the exon 25 (c.5428G>T p. $\mathrm{DI} 8 \mathrm{IOY}$ ) of Ovarian tissue. (D) Somatic DICERI missense mutation in exon 24 (c.5I26A>G p.DI709G) of thyroid tissue.

nonsense mutation (c.1088_1089delCTinsAA p.F363X) identified in the present study resides in exon 8 . According to previous studies, exon 8 of DICER 1 gene has a high frequency of disease-causing mutations. Bioinformatics prediction of pathogenicity by PolyPhen 2 and MutationTaster state that c.1088_1089delCTinsAA is a possibly damaging mutation, may be the disease causing. The case in our study indicates relatively low penetrance of the DICERI c.1088_1089delCTinsAA mutation. At the time of our study, the patient's mother and mother's family members did not have any signs of tumors. The relatively low penetrance of some DICER 1 mutations has also been reported in other studies. ${ }^{3}$ Hence, it is necessary to conduct clinical follow-up studies in patients who harbor pathogenic DICER1 mutations with or without tumorous diseases. Once a disease-causing mutation in the DICER 1 gene is found in a family member, it is recommended that relatives of all ages undergo genetic testing to provide screening recommendations for relatives with inherited disease-causing mutations for their age. ${ }^{4}$

Somatic mutations of DICER1 exist in the tumors of many of the patients who harbor germline mutations in this gene. Somatic mutations that affect the metal-binding sites of the RNase IIIb domain are called "hotspots".,13,14,16 Hotspot somatic mutations (D1709G and D1810Y) were also detected in our case. Tumor cells with DICER1 hotspot mutations often have loss of function defects in the other allele due to germline or other somatic events. And it is also indicating a "two-hit" tumor-suppressive model of DICER1. However, unlike classic "two-hit" models, these second "hits" of DICERl mutations generate a partially functional allele. ${ }^{13,16,17}$

Recognizing DICER1 syndrome has important clinical significance for patients and their family members and potential offspring, especially if cystic nephroma is found in very early childhood, more attention should be paid. In addition, few clinicians combine the rare SLCT with the more common MNG, more understanding and attention of co-occurrence of SLCT and MNG should be improved in the future. Clinicians should be alert to the existence of DICER1 mutations in these related diseases. Awareness of the DICER1 syndrome may result in early recognition of these rare pediatric tumors and appropriate therapeutic management.

\section{Informed Consent}

We have obtained the consent from the patient and patient's parents. We also obtained the consent to publish the case details and accompanying images. No institutional approval is required to publish case details. 
Table I Published Cases of SLCT+MNG with DICERI Mutations

\begin{tabular}{|c|c|c|c|c|c|}
\hline Study & Date & $\begin{array}{l}\text { Age at Diagnosis } \\
\text { of SLCT }\end{array}$ & $\begin{array}{l}\text { Age at Diagnosis of } \\
\text { MGN (or Thyroid } \\
\text { Cancer) }\end{array}$ & $\begin{array}{l}\text { Germline DICERI } \\
\text { Mutation }\end{array}$ & Somatic DICERI Mutation \\
\hline Jensen et $\mathrm{al}^{18}$ & 1974 & $\begin{array}{l}\text { Mother: } 13 \text { yrs } \\
\text { Daughter: } 18 \text { yrs }\end{array}$ & $\begin{array}{l}\text { Mother: } 13 \mathrm{yrs} \\
\text { Daughter: } 17 \mathrm{yrs}\end{array}$ & Unknown & Unknown \\
\hline $\begin{array}{l}\text { O'Brien and } \\
\text { Wilansky }\end{array}$ & 1981 & $18 \mathrm{yrs}$ & $16 \mathrm{yrs}$ & Unknown & Unknown \\
\hline Young and Scully ${ }^{20}$ & 1985 & $\begin{array}{l}\text { I case, age not } \\
\text { stated }\end{array}$ & Age not stated & Unknown & Unknown \\
\hline Niedziela $^{21}$ & 2008 & 14 yrs & $13 \mathrm{yrs}$ & Unknown & Unknown \\
\hline $\begin{array}{l}\text { Rio Frio et al } \\
(\text { Family C })^{8}\end{array}$ & 2011 & $32 \mathrm{yrs}$ & $18 \mathrm{yrs}$ & c.5018_502IdelTCAA & Unknown \\
\hline $\begin{array}{l}\text { Slade et al (Family } \\
17)^{22}\end{array}$ & 2011 & $12 \mathrm{yrs}$ & 9 yrs & $\begin{array}{l}\text { c.2988-2_2988- } \\
\text { I delAGinsCT }\end{array}$ & Unknown \\
\hline $\begin{array}{l}\text { Foulkes et al } \\
(\text { Family } 6)^{23}\end{array}$ & 2011 & $9 \mathrm{yrs}$ & $20 \mathrm{yrs}$ & c. $4050+$ I delG & Unknown \\
\hline $\begin{array}{l}\text { Ramasubramanian } \\
\text { et } \mathrm{al}^{24}\end{array}$ & 2013 & Before $16 \mathrm{yrs}$ & Before 16 yrs & Unknown & Unknown \\
\hline Darrat et $\mathrm{al}^{25}$ & 2013 & $\begin{array}{l}\text { Sibling 2: } \\
\text { SLCT (left), } 8 \text { yrs } \\
\text { SLCT (right), I } 4 \text { yrs }\end{array}$ & $14 \mathrm{yrs}$ & c. $1525 C>T$ & Unknown \\
\hline Schultz et $\mathrm{al}^{26}$ & 2014 & $13 \mathrm{yrs}$ & $\begin{array}{l}\text { Follicular variant of } \\
\text { papillary thyroid } \\
\text { Carcinoma,8 yrs }\end{array}$ & c. $1376+$ IG $>A$ & $\begin{array}{l}\text { c.5438 A>T in thyroid carcinoma; } \\
\text { c.5439G }>\mathrm{T} \text { (exon 25) in SLCT }\end{array}$ \\
\hline Wu et $\mathrm{al}^{27}$ & 2014 & $16 \mathrm{yrs}$ & 14 yrs & $\begin{array}{l}\text { c. } 3540 \mathrm{C}>\mathrm{A} \text { and } \mathrm{c} .4206 \\
+8 \text { insTT }\end{array}$ & Unknown \\
\hline Rossing et $\mathrm{al}^{3}$ & 2014 & $13 \mathrm{yrs}$ & $13 \mathrm{yrs}$ & $\begin{array}{l}\text { c. } 3647 \mathrm{C}>\mathrm{A} \text { and } \\
\text { c. } 3649 \mathrm{~T}>\mathrm{A}\end{array}$ & Unknown \\
\hline de Kock et $\mathrm{al}^{28}$ & 2016 & $\begin{array}{l}\text { SLCT (left), I } 3.4 \\
\text { yrs; } \\
\text { SLCT (right), I } 5.7 \\
\text { yrs }\end{array}$ & $\begin{array}{l}\text { Follicular variant of } \\
\text { papillary thyroid } \\
\text { Carcinoma, } 10.6 \text { yrs }\end{array}$ & c. $5437 G>C$ & c.4626-4626delG in SLCT (left) \\
\hline Durieux et $\mathrm{al}^{29}$ & 2016 & $\begin{array}{l}\text { Case I:17 yrs; } \\
\text { Case 2:15 yrs }\end{array}$ & $\begin{array}{l}\text { Case I:Follicular } \\
\text { variant of papillary } \\
\text { thyroid carcinoma, I8 } \\
\text { yrs; } \\
\text { Case 2: Follicular } \\
\text { variant of papillary } \\
\text { thyroid carcinoma, } 12 \\
\text { yrs }\end{array}$ & Unknown & $\begin{array}{l}\text { Case I: c.5II3G>A in SLCT; } \\
\text { Case 2: c. } 5 \text { I } 25 \mathrm{G}>\mathrm{A} \text { in SLCT; } \\
\text { c.5437G }>C \text { in thyroid carcinoma in } \\
\text { both cases }\end{array}$ \\
\hline Moke et al ${ }^{30}$ & 2018 & $13 \mathrm{yrs}$ & $\begin{array}{l}\text { Follicular variant of } \\
\text { papillary thyroid } \\
\text { carcinoma, } 13 \text { yrs }\end{array}$ & c.5504_5507delATCC & $\begin{array}{l}\text { c.5439G }>\mathrm{T} \text { in SLCT; c. } 5113 \mathrm{G}>\mathrm{A} \text { in } \\
\text { thyroid carcinoma }\end{array}$ \\
\hline
\end{tabular}

(Continued) 
Table I (Continued).

\begin{tabular}{|c|c|c|c|c|c|}
\hline Study & Date & $\begin{array}{l}\text { Age at Diagnosis } \\
\text { of SLCT }\end{array}$ & $\begin{array}{l}\text { Age at Diagnosis of } \\
\text { MGN (or Thyroid } \\
\text { Cancer) }\end{array}$ & $\begin{array}{l}\text { Germline DICERI } \\
\text { Mutation }\end{array}$ & Somatic DICERI Mutation \\
\hline $\begin{array}{l}\text { Apellaniz-Ruiz } \\
\text { et } \mathrm{al}^{7}\end{array}$ & 2018 & Proband: 13 yrs & Proband: 15 yrs & $\begin{array}{l}\text { c.4207-4I_5364 } \\
+ \text { l034del }\end{array}$ & $\begin{array}{l}\text { c. } 5437 \mathrm{G}>\mathrm{C} \text { in } \mathrm{SLCT} ; \mathrm{c} .5 \mathrm{I} \mid \mathrm{BG}>\mathrm{C} \text {, and } \\
\text { c. } 5 \mathrm{I} \text { I } 4 \mathrm{~A}>\mathrm{T} \text { in } \mathrm{MGN}\end{array}$ \\
\hline Cowan et $\mathrm{al}^{31}$ & 2018 & After 17 yrs & $12 \mathrm{yrs}$ & c.904-IG >C & c.5425G > A in SLCT \\
\hline Chen et $\mathrm{al}^{32}$ & 2018 & $15 \mathrm{yrs}$ & $\begin{array}{l}\text { Thyroid follicular } \\
\text { adenoma, } 12 \text { yrs }\end{array}$ & c.3307_33IIdelGACAG & $\begin{array}{l}\text { c.5439G > T in SLCT (left); } \\
\text { c.5439G >C in SLCT (right); } \\
\text { c.5439G > T in thyroid follicular } \\
\text { adenoma }\end{array}$ \\
\hline Haley et $\mathrm{al}^{9}$ & 2019 & Mother: $38 \mathrm{yrs}$ & Age not stated & c. $325 \mathrm{C}>\mathrm{T}$ & Unknown \\
\hline Zhang et $\mathrm{al}^{33}$ & 2020 & Proband:2I yrs & Proband:20 yrs & Unknown & c.51।3G $>A$ and c. $2403 C>A$ in SLCT \\
\hline
\end{tabular}

\section{Acknowledgments}

The authors thank the technical assistance in genetic analysis from MyGenostics Inc.

\section{Disclosure}

The authors report no conflicts of interest in this work.

\section{References}

1. Witkowski L, Mattina J, Schönberger S, et al. DICER1 hotspot mutations in non-epithelial gonadal tumours. Br J Cancer. 2013;109 (10):2744-2750. doi:10.1038/bjc.2013.637

2. Bahubeshi A, Tischkowitz M, Foulkes WD. miRNA processing and human cancer: DICER1 cuts the mustard. Sci Transl Med. 2011;3 (111):111ps146. doi:10.1126/scitranslmed.3002493

3. Rossing M, Gerdes AM, Juul A, et al. A novel DICER1 mutation identified in a female with ovarian Sertoli-Leydig cell tumor and multinodular goiter: a case report. J Med Case Rep. 2014;8:112. doi:10.1186/1752-1947-8-112

4. Schultz KAP, Williams GM, Kamihara J, et al. DICER1 and associated conditions: identification of at-risk individuals and recommended surveillance strategies. Clin Cancer Res. 2018;24(10):2251-2261. doi:10.1158/1078-0432.CCR-17-3089

5. Lantzsch T, Stoerer S, Lawrenz K, Buchmann J, Strauss HG, Koelbl H. Sertoli-Leydig cell tumor. Arch Gynecol Obstet. 2001;264 (4):206-208. doi:10.1007/s004040000114

6. de Kock L, Terzic T, McCluggage WG, et al. DICER1 mutations are consistently present in moderately and poorly differentiated Sertoli-Leydig cell tumors. Am $J$ Surg Pathol. 2017;41 (9):1178-1187. doi:10.1097/PAS.0000000000000895

7. Apellaniz-Ruiz M, de Kock L, Sabbaghian N, et al. Familial multinodular goiter and Sertoli-Leydig cell tumors associated with a large intragenic in-frame DICER1 deletion. Eur J Endocrinol. 2018;178(2): K11-k19. doi:10.1530/EJE-17-0904

8. Rio Frio T, Bahubeshi A, Kanellopoulou C, et al. DICER1 mutations in familial multinodular goiter with and without ovarian Sertoli-Leydig cell tumors. JAMA. 2011;305(1):68-77. doi:10.1001/jama.2010.1910
9. Haley M, Bindal P, McAuliffe A, Vredenburgh J. A family with Sertoli-Leydig cell tumour, multinodular goiter, and DICER1 mutation. Curr Oncol. 2019;26(3):183-185. doi:10.3747/co.26.4727

10. Kurian JJ, Sen S, Joseph RT, Bindra MS. A rare case of bilateral cystic nephroma associated with embryonal rhabdomyosarcoma of the penile urethra. J Indian Assoc Pediatr Surg. 2015;20(2):82-83. doi:10.4103/0971-9261.151553

11. Stamatiou K, Polizois K, Kollaitis G, et al. Cystic nephroma: a case report and review of the literature. Cases J. 2008;1(1):267. doi:10.1186/1757-1626-1-267

12. Bahubeshi A, Bal N, Rio Frio T, et al. Germline DICER1 mutations and familial cystic nephroma. J Med Genet. 2010;47(12):863-866. doi:10.1136/jmg.2010.081216

13. Heravi-Moussavi A, Anglesio MS, Cheng SW, et al. Recurrent somatic DICER1 mutations in nonepithelial ovarian cancers. $N$ Engl J Med. 2012;366(3):234-242.

14. Doros LA, Rossi CT, Yang J, et al. DICER1 mutations in childhood cystic nephroma and its relationship to DICER1-renal sarcoma. Mod Pathol. 2014;27(9):1267-1280. doi:10.1038/modpathol.2013.242

15. Apellaniz-Ruiz M, Segni M, Kettwig M, et al. Mesenchymal hamartoma of the liver and DICER1 syndrome. N Engl J Med. 2019;380 (19):1834-1842. doi:10.1056/NEJMoa1812169

16. Anglesio MS, Wang Y, Yang W, et al. Cancer-associated somatic DICER1 hotspot mutations cause defective miRNA processing and reverse-strand expression bias to predominantly mature $3 \mathrm{p}$ strands through loss of 5p strand cleavage. J Pathol. 2013;229(3):400-409. doi:10.1002/path.4135

17. Wang Y, Chen J, Yang W, et al. The oncogenic roles of DICER1 RNase IIIb domain mutations in ovarian Sertoli-Leydig cell tumors. Neoplasia. 2015;17(8):650-660. doi:10.1016/j.neo.2015.08.003

18. Jensen RD, Norris HJ, Fraumeni JF Jr. Familial arrhenoblastoma and thyroid adenoma. Cancer. 1974;33(1):218-223. doi:10.1002/10970142(197401)33:1<218::AID-CNCR2820330132>3.0.CO;2-Z

19. O'Brien PK, Wilansky DL. Familial thyroid nodulation and arrhenoblastoma. Am J Clin Pathol. 1981;75(4):578-581. doi:10.1093/ajcp/75.4.578

20. Young RH, Scully RE. Ovarian Sertoli-Leydig cell tumors. A clinicopathological analysis of 207 cases. Am J Surg Pathol. 1985;9(8):543-569. doi:10.1097/00000478-198508000-00001 
21. Niedziela M. Virilizing ovarian tumor in a 14-year-old female with a prior familial multinodular goiter. Pediatr Blood Cancer. 2008;51 (4):543-545. doi:10.1002/pbc.21675

22. Slade I, Bacchelli C, Davies H, et al. DICER1 syndrome: clarifying the diagnosis, clinical features and management implications of a pleiotropic tumour predisposition syndrome. $J$ Med Genet. 2011;48(4):273-278. doi:10.1136/jmg.2010.083790

23. Foulkes WD, Bahubeshi A, Hamel N, et al. Extending the phenotypes associated with DICER1 mutations. Hum Mutat. 2011;32 (12):1381-1384. doi:10.1002/humu.21600

24. Ramasubramanian A, Correa ZM, Augsburger JJ, Sisk RA, Plager DA. Medulloepithelioma in DICER1 syndrome treated with resection. Eye. 2013;27(7):896-897. doi:10.1038/eye.2013.87

25. Darrat I, Bedoyan JK, Chen M, Schuette JL, Lesperance MM. Novel DICER1 mutation as cause of multinodular goiter in children. Head Neck. 2013;35(12):E369-371. doi:10.1002/hed.23250

26. Schultz KA, Yang J, Doros L, et al. DICER1-pleuropulmonary blastoma familial tumor predisposition syndrome: a unique constellation of neoplastic conditions. Pathol Case Rev. 2014;19(2):90-100. doi:10.1097/PCR.0000000000000027

27. Wu Y, Chen D, Li Y, Bian L, Ma T, Xie M. DICER1 mutations in a patient with an ovarian Sertoli-Leydig tumor, well-differentiated fetal adenocarcinoma of the lung, and familial multinodular goiter. Eur J Med Genet. 2014;57(11-12):621-625. doi:10.1016/j.ejmg.2014.09.008
28. de Kock L, Wang YC, Revil T, et al. High-sensitivity sequencing reveals multi-organ somatic mosaicism causing DICER1 syndrome. JMed Genet. 2016;53(1):43-52. doi:10.1136/jmedgenet-2015-103428

29. Durieux E, Descotes F, Mauduit C, Decaussin M, Guyetant S, Devouassoux-Shisheboran M. The co-occurrence of an ovarian Sertoli-Leydig cell tumor with a thyroid carcinoma is highly suggestive of a DICER1 syndrome. Virchows Arch. 2016;468(5):631-636. doi:10.1007/s00428-016-1922-0

30. Moke DJ, Thomas SM, Hiemenz MC, et al. Three synchronous malignancies in a patient with DICER1 syndrome. Eur J Cancer. 2018;93:140-143. doi:10.1016/j.ejca.2017.12.021

31. Cowan M, Suntum T, Olivas AD, et al. Second primary rhabdomyosarcoma of the uterine cervix presenting with synchronous ovarian Sertoli-Leydig cell tumor: an illustrative case of DICER1 syndrome. Gynecol Oncol Rep. 2018;25:94-97. doi:10.1016/j.gore.2018.06.008

32. Chen KS, Stuart SH, Stroup EK, et al. Distinct DICER1 hotspot mutations identify bilateral tumors as separate events. JCO Precis Oncol. 2018;2. doi:10.1200/PO.17.00113

33. Zhang Y, Ren M, Hong Y, et al. Sertoli-Leydig cell tumor in two siblings with DICER1 syndrome: a case report and literature review. Medicine. 2020;99(27):e20806. doi:10.1097/MD.0000000000020806

\section{Publish your work in this journal}

Pharmacogenomics and Personalized Medicine is an international, peer-reviewed, open access journal characterizing the influence of genotype on pharmacology leading to the development of personalized treatment programs and individualized drug selection for improved safety, efficacy and sustainability. This journal is indexed on the American Chemical Society's Chemical Abstracts Service (CAS). The manuscript management system is completely online and includes a very quick and fair peer-review system, which is all easy to use. Visit http://www.dovepress.com/testimonials.php to read real quotes from published authors. 